\title{
Annual proxy data from Lago Grande di Monticchio (southern Italy) between 76 and 112 ka: new chronological constraints and insights on abrupt climatic oscillations
}

\author{
C. Martin-Puertas, A. Brauer, S. Wulf, F. Ott, S. Lauterbach, and P. Dulski \\ GFZ, German Research Centre for Geosciences, Section 5.2 Climate Dynamics and Landscape Evolution, Telegrafenberg, \\ 14473 Potsdam, Germany
}

Correspondence to: C. Martin-Puertas (celia@gfz-potsdam.de)

Received: 6 June 2014 - Published in Clim. Past Discuss.: 26 June 2014

Revised: 17 October 2014 - Accepted: 22 October 2014 - Published: 1 December 2014

\begin{abstract}
We present new annual sedimentological proxies and sub-annual element scanner data from the Lago Grande di Monticchio (MON) sediment record for the sequence 76-112 thousand years before present (ka). They are combined with the previously published decadal to centennial resolved pollen assemblage in order to provide a comprehensive reconstruction of six major abrupt stadial spells (MON 1-6) in the central Mediterranean during the early phase of the last glaciation. These climatic oscillations are defined by intervals of thicker varves and high Ti-counts and coincide with episodes of forest depletion interpreted as Mediterranean stadial conditions (cold winter/dry summer). Our chronology, labelled as MON-2014, has been updated for the study interval by tephrochronology and repeated and more precise varve counts and is independent from ice-core and speleothem chronologies. The high-resolution Monticchio data then have been compared in detail with the Greenland ice-core $\delta^{18} \mathrm{O}$ record (NorthGRIP) and the northern Alps speleothem $\delta^{18} \mathrm{O}_{\text {calcite }}$ data (NALPS). Based on visual inspection of major changes in the proxy data, MON 2-6 are suggested to correlate with Greenland stadials (GS) 25-20. MON 1 (Woillard event), the first and shortest cooling spell in the Mediterranean after a long phase of stable interglacial conditions, has no counterpart in the Greenland ice core, but coincides with the lowest isotope values at the end of the gradual decrease in $\delta^{18} \mathrm{O}_{\text {ice }}$ in NorthGRIP during the second half of the Greenland interstadial (GI) 25. MON 3 is the least pronounced cold spell and shows gradual transitions, whereas its NorthGRIP counterpart GS 24 is characterized by sharp changes in the isotope records. MON 2 and MON 4 are the longest and most pronounced oscillations
\end{abstract}

in the MON sediments in good agreement with their counterparts identified in the ice and spelethem records. The length of MON 4 (correlating with GS 22) supports the duration of stadial proposed by the NALPS timescales and suggests ca. 500 year longer duration than calculated by the ice-core chronologies GICC05 modelext and AICC2012. Absolute dating of the cold spells provided by the MON-2014 chronology shows good agreement among the MON-2014, the GICC05 modelext and the NALPS timescales for the period between 112 and $100 \mathrm{ka}$. In contrast, the MON-2014 varve chronology dates the oscillations MON 4 to MON 6 (92-76 ka) as ca. 3500 years older than the most likely corresponding stadials GS 22 to GS 20 by the other chronologies.

\section{Introduction}

The initial build-up of the Northern Hemisphere (NH) ice sheets (early glaciation) spanned from 122 to ca. 70 thousand years before present (hereafter ka); however, the ice sheet expansion was interrupted by millennial-scale recurrent phases of ice retreat (Mangerud et al., 1998). In the NorthGRIP $\delta^{18} \mathrm{O}_{\text {ice }}$ record, these periods of waxing and waning of ice sheets are mirrored by abrupt climate changes between relatively warm and humid (higher $\delta^{18} \mathrm{O}_{\text {ice }}$ values) interstadials (GI 20-25) and cold and dry (lower $\delta^{18} \mathrm{O}_{\text {ice }}$ ) stadials (GS 26-20) (NorthGRIP project members, 2004). The existence of these GIs and GSs responds to the millennialscale climate variability known as Dansgaard-Oeschger oscillation (D-O) that characterized the whole Last Glacial 
period (Dansgaard et al., 1993). In the marine realm, the early glacial period in turn spans marine isotope sub-stages MIS $5 \mathrm{~d}-\mathrm{a}$, which reflect alternation of increased (MIS $5 \mathrm{~d}$ and $5 \mathrm{~b}$ ) and reduced (MIS 5c and 5a) global ice volume phases (Shackleton, 1987). Sea surface temperatures reconstructed for the central-eastern North Atlantic also show millennial-scale climate variability consisting of cold pulses (C25-20) and warm episodes (W24-20) (McManus et al., 1994; Sánchez Goñi et al., 1999; Shackleton et al., 2002). In central Europe, vegetation changes recorded in La Grande Pile lake sequence also describe millennial-scale variability from $\sim 111 \mathrm{ka}$ alternating between periods characterized by reduced tree-pollen size (stadials) known as Woillard event, Melisey 1 and 2 and Montaigu event, and stages identified as episodes of forest development (interstadials) named St. Germain 1 and St. Germain 2 (Kukla, 1997). In the central Mediterranean, these oscillations are also reflected in the pollen record of Lago Grande di Monticchio, in southern Italy, between 111 and $80 \mathrm{ka}$ (Allen et al., 1999; Brauer et al., 2007) and in the isotope record of the Corchia Cave spleothem, in central Italy (Drysdale et al., 2007).

The evidence that millennial-scale climate variability affected the North Atlantic and European region leads to challenging questions related to the nature of climatic triggers and feedback mechanisms behind the generation and propagation of these abrupt climate changes, as well as the possible regional synchronicity of timing and duration of the rapid climate oscillations. Unfortunately, investigations covering this timeframe are limited because of the lack of continuous high-resolution records covering this time period, but also because robust dating is more difficult since this period is outside the interval covered by radiocarbon dating. Therefore, the abrupt climate changes during the early last glacial period (MIS 5d-a) have been less understood than the rapid events within the full glacial conditions (MIS 3). Besides the $\delta^{18} \mathrm{O}_{\text {ice }}$ NorthGRIP ice core record, the U/Th-dated $\delta^{18} \mathrm{O}_{\text {calcite }}$ speleothem record in the Northern Alps (NALPS) (Boch et al., 2011) provides a temperature-sensitive proxy record with resolution higher than 20 years and comparable to the NorthGRIP ice core. These two high-resolution archives show similar climate variability and reveal rapid temperature changes superimposed onto the millennial-scale variability (Capron et al., 2010; Boch et al., 2011). However, a detailed discussion about regional synchronicity is still hampered by the large dating uncertainty due to limitations in the chronologies. The NorthGRIP ice core record is not annually layered beyond $60 \mathrm{ka}$, hence the age depth models show bigger absolute uncertainties: for instance, the GICC05 modelext timescale, which is based on data from the Greenland ice core records (Wolff et al., 2010), and the AICC2012 chronology, which was developed for four Antarctic ice cores and the NorthGRIP record (Bazin et al., 2013; Veres et al., 2013). On the other hand, the NALPS chronology provides good dates but the record shows discontinuities during the stadial periods, when the stalagmites stopped growing due to cooler conditions. Thus, there are still dating differences of several millennia between the ice-core chronologies and between those and the NALPS timescale (Veres et al., 2013).

The sediment record from Lago Grande di Monticchio (MON) is annually laminated. This record provides an absolute timescale for the early last glacial period based on varve counting, tephrochronology and ${ }^{40} \mathrm{Ar} /{ }^{39} \mathrm{Ar}$ dating of tephra layers (Allen et al., 1999; Brauer et al., 2000, 2007; Wulf et al., 2004, 2012). However, still today the main focus of investigations has been on vegetation changes at decadal to centennial resolution (Allen et al., 1999; Brauer et al., 2007). In this study we present varve micro-facies and thickness analyses in combination with high-resolution X-ray fluorescence (XRF)-element scanning data. This is a rare annually resolved continental record of the early glaciation in the Mediterranean (112-76 ka), which enables (1) a robust comparison based on absolute dating between high-resolution paleoclimatic records originated from different paleoclimate archives (i.e. the MON sediment record, the NorthGRIP $\delta^{18} \mathrm{O}_{\text {ice }}$ and the NALPS $\delta^{18} \mathrm{O}_{\text {calcite }}$ ), (2) the identification of sub-millennial scale climate variability in the Mediterranean, and (3) an attempt at proving possible regional differences among the compared climate archives within the range of age uncertainty.

\section{Regional setting}

Lago Grande di Monticchio (MON) $\left(40^{\circ} 56^{\prime} \mathrm{N}, 15^{\circ} 35^{\prime} \mathrm{E}\right.$, $656 \mathrm{~m}$ a.s.1.) is located in the Basilicata region of southern Italy (Fig. 1). The lake is the largest of two adjacent maar lakes within a caldera on the western slope of Monte Vulture, a Quaternary volcano in the Roman Co-magmatic Province, and was formed at $132 \pm 12 \mathrm{ka}$ during the final phreatomagmatic eruptions of Monte Vulture (Brocchini et al., 1994; Stoppa and Principe, 1998). The lake surface area is $0.4 \mathrm{~km}^{2}$ and the catchment covers $2.37 \mathrm{~km}^{2}$, which is mainly composed of K-alkaline phonotephrites and tephrifoidites (Hieke Merlin, 1967). The maximum depth is of $36 \mathrm{~m}$ on the northern part of the basin, but two-thirds of the lake is less than $12 \mathrm{~m}$ deep. The maximum elevation in the catchment is $956 \mathrm{~m}$ a.s.l., with a maximum relief of $300 \mathrm{~m}$. MON is considered a closed lake since no major in- or outflows exist. The trophic state of the present lake is eutrophic to hypertrophic. The climate at MON is characterized by wet winters and pronounced dry summers (Watts, 1996). Most of the annual precipitation (63\% of $815 \mathrm{~mm}$ mean annual precipitation) falls between October and March.

The geographical location of MON is in a favourable downwind position to the active volcanoes of the alkaline Roman Co-magmatic Province, as well as being close to the active volcanic centres of the Aeolian Islands $(280 \mathrm{~km})$, Mount Etna $(360 \mathrm{~km})$ and the Island of Pantelleria in the Strait of Sicily $(540 \mathrm{~km})$ (Fig. 1). Some of these eruptions were highly 


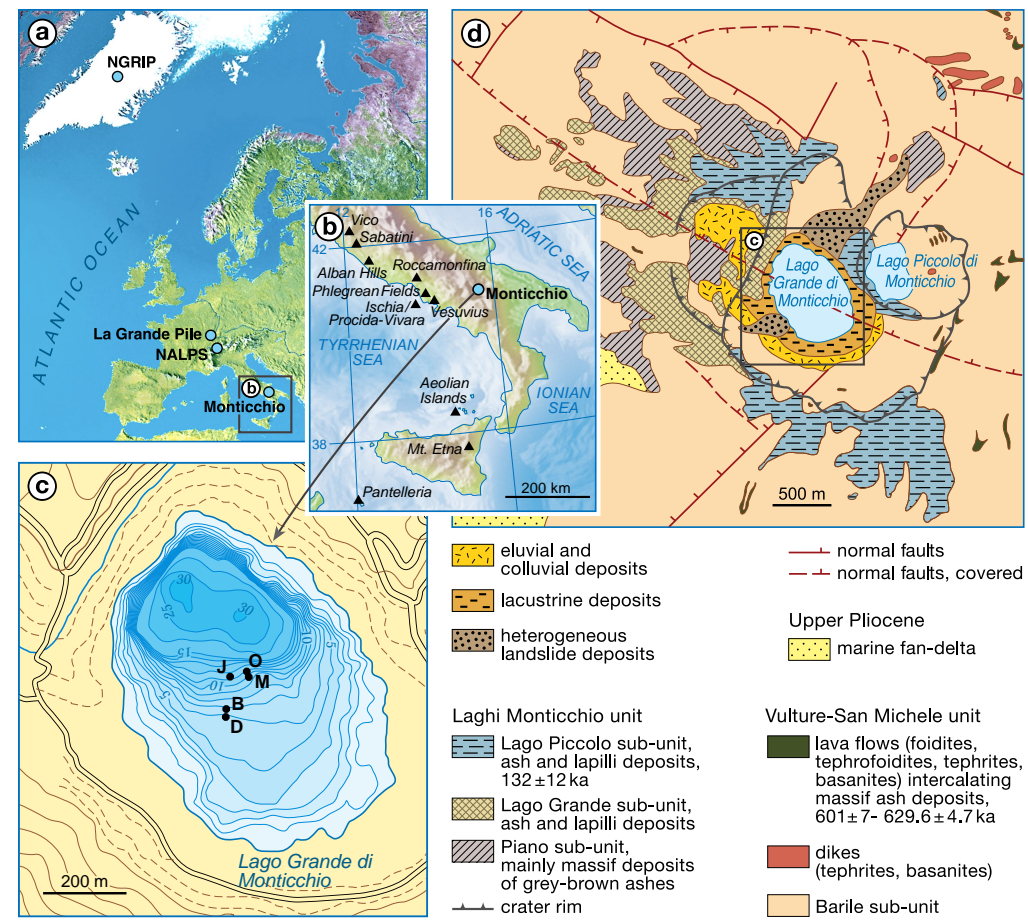

Figure 1. (a) Location of Lago Grande di Monticchio and the sites mentioned in the text and used for comparison. (b) Major volcanic centres in the study region. (c) Bathymetry of the lake and coring sites. (d) Geological map of the catchment of the lake.

explosive in the past, and the erupted tephra material was widely dispersed in the central Mediterranean and also deposited in the MON sediments (Narcisi, 1996; Wulf et al., 2004).

\section{Material and methods}

Three long sediment cores used for this study were collected from Lago Grande di Monticchio at $13.5 \mathrm{~m}$ of water depth using the USINGER piston corer during different coring campaigns in 1994 and 2000. Core $\mathrm{J}$ (1994) is $65 \mathrm{~m}$ long and shows a continuous sequence of laminated sediments. Cores M/O (2000) were taken nearby and extend the laminated record to a length of $102.3 \mathrm{~m}$ (Brauer et al., 2007; Fig. 1). Sediment cores were split, imaged, described and correlated using macro- and microscopic marker tephras (Brauer et al., 2007). $32 \mathrm{~m}$ of the composite profile from cores M/O (67.45-74.67 m) and core J (40.92-64.98 m) were re-analysed for this study including varve counting, varve thickness measurements and micro-facies analyses. Microscopic analyses were carried out on a complete series of $2 \mathrm{~cm}$ overlapping thin sections using a petrographic microscope under parallel and polarized light. Thin sections $(100 \times 20 \mathrm{~mm})$ were prepared following the procedures described by Brauer et al. (2000). Varve counting was carried out applying two approaches: (method 1) overview counting of number of varves per $\mathrm{cm}$ at low microscopic mag- nification $(50 \times)$, (method 2) counting based on thickness measurements for each varve at higher microscopic magnification $(100 \times)$. Method 2 is regarded as more precise and has been applied for the first time for the MON sediments in this study. Varve counts obtained through method 2 (one counter) were compared to a previous counting (method 1) that had been performed by two different counters (Allen et al., 1999; Brauer et al., 2000, 2007) using a total of 132 tephra layers as correlation marker along the study interval. The comparison of both counts between distinct tephra marker layers allows calculating a precise (relative) counting error estimate for the study interval in addition to the previously published gross error estimates for the entire record (Allen et al., 1999; Brauer et al., 2007). Elemental composition of the sediments was measured using an ITRAX $\mu$-XRF core scanner directly on the sediment cores with a step size of $300 \mu \mathrm{m}$ resolution using a Cr-tube, $30 \mathrm{kV}$ tube voltage, a tube current of $30 \mathrm{~mA}$ and $10 \mathrm{~s}$ exposure time. The $\mu$-XRF results are expressed as element intensities in counts. The high-resolution measurements provide $1-15$ data points per varve depending on the annual sedimentation rate. 1354 marker (tephra and sedimentological) layers were used to transfer the $\mu$-XRF data on timescale using the varve counting-based age-depth model performed for the sedimentary record. Pollen data have been previously published by Allen et al. (1999) and by Brauer et al. (2007). The sediments were prepared for pollen analysis by standard procedures (detailed information in Watts, 1996) with resolution between 2 and $20 \mathrm{~cm}$. 

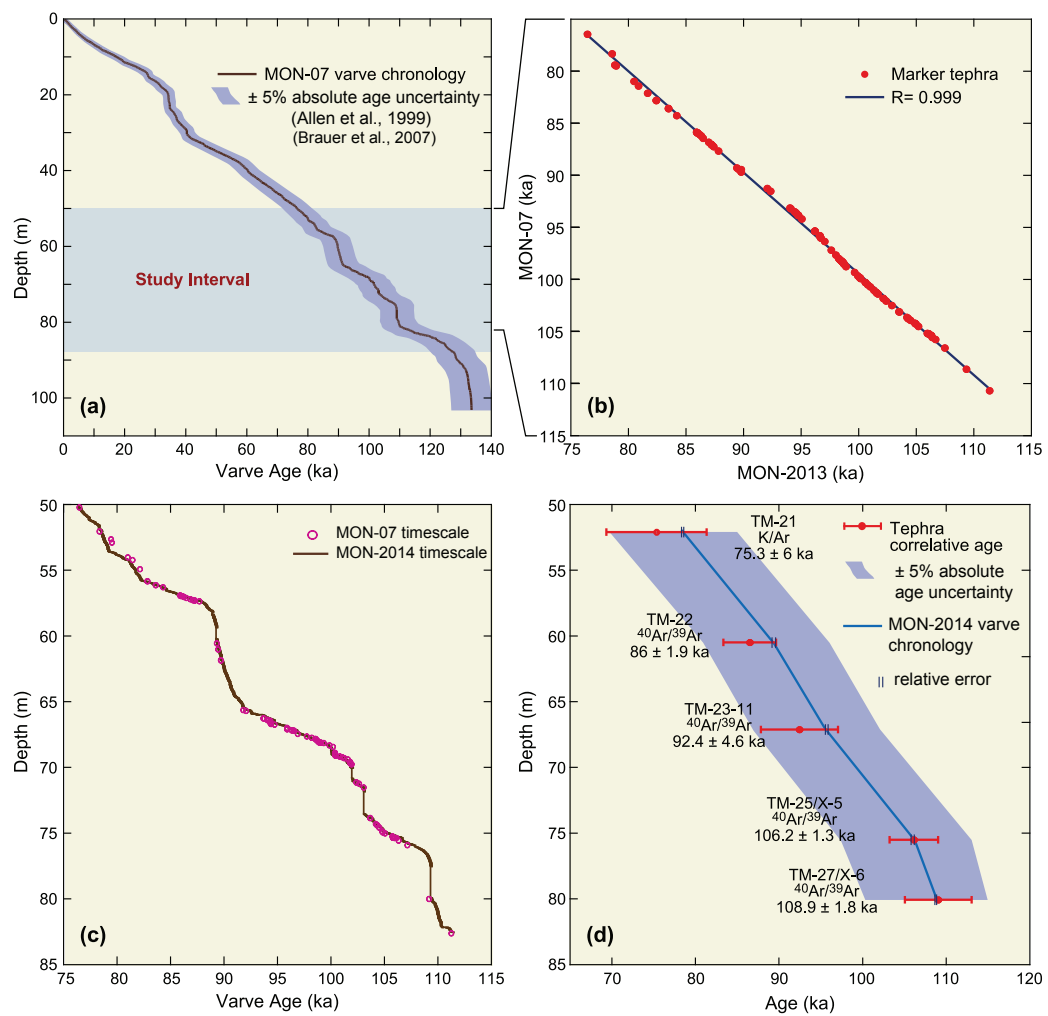

Figure 2. Varve chronology of the Lago Grande di Monticchio sedimentary record: (a) MON-07 age-depth model for the last 133 kyr as derived from varve counting (Brauer et al., 2007). Error bars showing the $\pm 5 \%$ error range for absolute ages. (b) Comparison between MON-07 and MON-2014 varve counts for the study interval (76-112 ka). (c) MON-07 and MON-2014 age-depth models (this study). (d) Comparison of the MON-2014 timescale and radiometric ages of tephra correlatives.

\section{Results}

\subsection{Varve counting and tephrochronology}

The published varve chronology of the MON sediments (Brauer et al., 2007) is an independent chronology based on (1) varve counting (method 1) in sections where annual laminations have been recognized, and (2) a detailed calculation of sedimentation rates in sections where varves were poorly or not preserved using varve thickness measurements from adjacent varved sections (Zolitschka and Negendank, 1996). Tephra and turbidite layers were excluded from counting as non-annual events. The counting was from top to bottom, i.e. from young to old, and the whole chronology was established in two phases of counting: (1) from the present day back to $102 \mathrm{ka}$ (MON-99), the chronology was developed on the composite profile B/D and core J (Allen et al., 1999); and (2) extended on the composite profile M/O for the interval 102 to $133 \mathrm{ka}$ and a revision of the interval between 19.3 and $36.8 \mathrm{ka}$ (MON-07; Brauer et al., 2007). The mean estimated accumulative varve counting error (absolute age uncertainty) is $\pm 5 \%$ (Fig. 2a) and varve chronology is supported by ${ }^{40} \mathrm{Ar} /{ }^{39} \mathrm{Ar}$ dates of major tephras and tephrochronology (Wulf et al., 2012). Since the MON-07 chronology is based on combination of varve counting, varve interpolation and tephra ages, absolute ages are expressed as "a".

For the present study, the MON-07 chronology has been re-examined by performing detailed varve counting (method 2) on a new composite profile $\mathrm{J} / \mathrm{M} / \mathrm{O}$ for the interval 76-112 ka (MON-2014). Thereby, three previously unidentified missing varve intervals have been noticed in core $\mathrm{J}$ within the interval $102.5-90.5 \mathrm{ka}$, which are now bridged by additional varve counts in the composite M/O. Based on these counts, a total of 510 additional varves have been counted and included in the new MON-2014 chronology. The revised chronology (MON-2014) is in very good agreement $(r=0.999)$ with the MON-07 chronology (including the 510 missing varves) (Fig. 2b). There is a maximum divergence of 582 varves between the tephra layers TM-21 (78.47 ka) and TM 21-1a (79.12 ka), and a minimum divergence of 11 varves between the tephra layers TM-24-2a (104.18 ka) and TM24-2b (104.28 ka) (Fig. 2c; for the full description of the MON tephra layers see Wulf et al., 2004, 2012). The detailed comparison between the MON-07 and the MON-2014 varve counts allows us, in addition to the gross error range of $\pm 5 \%$ given for the absolute ages of entire record (Allen et al., 1999; Brauer et al., 2007), to 
Table 1. Timing and duration of climatic oscillations MON 1-6 and their transitions (abruptness of varve thickness changes) onto the MON2014 timescale. Correlative events in terrestrial, marine and ice core stratigraphies across from Greenland to the Mediterranean are given for comparison. Uncertainty of absolute varve ages is given by the $\pm 5 \%$ accumulative counting error. Uncertainty on the duration of the MON oscillation is calculated from the differences between the MON-07 and the MON-2014 counts for those particular interval where the climate oscillation occur (Fig. 2c).

\begin{tabular}{|c|c|c|c|c|c|c|c|c|c|}
\hline $\begin{array}{l}\text { MON } \\
\text { oscillations } \\
\text { varve- } \\
\text { defined }\end{array}$ & $\begin{array}{l}\text { From } \\
\text { (a) }\end{array}$ & $\begin{array}{l}\text { Transition } \\
\text { (varve yr) }\end{array}$ & $\begin{array}{l}\text { To } \\
\text { (a) }\end{array}$ & $\begin{array}{l}\text { Transition } \\
\text { (varve yr) }\end{array}$ & $\begin{array}{l}\text { Duration } \\
\text { (varve yr) }\end{array}$ & $\begin{array}{l}\text { Pollen- } \\
\text { defined } \\
\text { intervals }\end{array}$ & $\begin{array}{l}\text { North } \\
\text { Atlantic } \\
\text { correlates }\end{array}$ & $\begin{array}{l}\text { Greenland } \\
\text { correlates }\end{array}$ & MIS \\
\hline MON 1 & $111230 \pm 5561$ & 0 & $111013 \pm 5550$ & 1 & $217 \pm 4$ & Woillard & $\mathrm{C} 25$ & & $5 \mathrm{~d}$ \\
\hline MON 2 & $110429 \pm 5521$ & 7 & $108630 \pm 5431$ & 20 & $1798 \pm 69$ & Melisey 1 & $\mathrm{C} 24$ & GS 25 & $5 d$ \\
\hline MON 3 & $105500 \pm 5275$ & 33 & $103000 \pm 5150$ & 153 & $2500 \pm 142$ & Montaigu & $\mathrm{C} 23$ & GS 24 & $5 c$ \\
\hline MON 4 & $92069 \pm 4603$ & 11 & $88907 \pm 4445$ & 11 & $3162 \pm 83$ & Melisey 2 & $\mathrm{C} 21$ & GS 22 & $5 b$ \\
\hline MON 5 & $82583 \pm 4129$ & 3 & $81120 \pm 4056$ & 7 & $1463 \pm 17$ & PAZ 17d & & GS 21 & $5 a$ \\
\hline MON 6 & $79307 \pm 3965$ & 3 & $76715 \pm 3835$ & 13 & $2592 \pm 413$ & PAZ 17b & & GS 20 & $5 a$ \\
\hline
\end{tabular}

provide a betterconstrained and more precise error estimate for the study interval. We apply this relative error as uncertainty range for the durations of the climate oscillations (Table 1). The MON-2014 count is anchored to the MON-07 chronology at the tephra layer TM 20-8 located on the top of the study interval and dated at $76468 \pm 3823 \mathrm{a}( \pm 5 \%$ error range) (Wulf et al., 2012). The age-depth model along the study interval exhibits large changes in the sedimentation rate (Fig. 2c), which is partly explained by the deposition of tephra layers up to several metres thick. In order to assess the uncertainties in the varve counts, the ages of five reliably correlated and well-dated tephra layers (Wulf et al., 2004, 2012) have been compared to the MON-2014 varve age (Fig. 2d). These tephras are (1) TM-21 (Petrazza Tuffs/Stromboli, $75.3 \pm 6 \mathrm{ka} \mathrm{K} /$ Ar; Gillot and Keller, 1993), (2) TM-22 (Ignimbrite Z/Pantelleria, $86 \pm 1.9 \mathrm{ka}{ }^{40} \mathrm{Ar} /{ }^{39} \mathrm{Ar}$; Rotolo et al., 2013), (3) TM-23-11 (POP-1 tephra/Campanian Province, $92.4 \pm 4.6 \mathrm{ka}{ }^{40} \mathrm{Ar} /{ }^{39} \mathrm{Ar}$; Giaccio et al., 2012), (4) TM-25 (X-5 tephra/Campanian Province, $106.2 \pm 1.3 \mathrm{ka}$ ${ }^{40} \mathrm{Ar} /{ }^{39} \mathrm{Ar}$; Giaccio et al., 2012) and (5) TM-27 (X6 tephra/Campanian Province, $108.9 \pm 1.8 \mathrm{ka}{ }^{40} \mathrm{Ar} /{ }^{39} \mathrm{Ar}$; Iorio et al., 2014). The varve ages of tephras TM-27 $(109.26 \pm 0.1 \mathrm{ka})$ and TM-25 $(106.50 \pm 0.19 \mathrm{ka})$ are in good agreement with the age of the correlative tephras X5 and X6, but the varve chronology provides older ages for the tephras TM-23-11 (96.05 $\pm 0.16 \mathrm{ka}), \mathrm{TM}-22(89.37 \pm 0.06 \mathrm{ka})$ and TM-21 (78.47 $\pm 0.12 \mathrm{ka}$ ) by $\sim 3500$ years (Fig. $2 \mathrm{c})$. The error range given for the varve ages of the tephra is based on difference between the MON-2014 and MON-07 counts. Comparison between varve- and tephra dating agree each other on absolute ages for the period 110-106 ka with differences less than $0.5 \%$, but up to $4 \%$ differences for the period 96-78 ka which, however, is still within the uncertainty of $\pm 5 \%$ for absolute ages (Fig. 2d). If the observed increasing difference between varve and tephra ages between 106 and $96 \mathrm{ka}$ is real and caused by varve counting, we must assume either a varve underestimation or a sediment hiatus in this interval. However, we do not find any sedimentological indication for a hiatus and double varve counting in the $\mathrm{J}$ and $\mathrm{M} / \mathrm{O}$ profiles always revealed about the same number of varves.

\subsection{Microfacies analyses}

The study interval covers the transition from the last interglacial to glacial deposits $(112-76 \mathrm{ka})$ in the MON record and is represented by a $32.35 \mathrm{~m}$ long interval predominantly consisting of finely organic varved sediments intercalated with intervals of more clastic varved sediments. Centimetreto millimetre-thick deposits of reworked littoral sediments (minerogenic and organic detritus and tephra material) and 132 primary tephra fallout layers are randomly stratified in the laminated sequence. Varves are heterogeneous and seasonality is expressed by two or three of the following sublayers: (i) a diatom layer as a result of the spring-summer peak of productivity in the lake; (ii) a detritus layer and (iii) an authigenic siderite layer. Occasionally, endogenic calcite precipitation occurs in an additional late-spring/earlysummer sub-layer (Fig. 3a, b).

On the basis of varve composition, two major micro-facies types distinguish organic varves (microfacies 1 ) from siderite varves (microfacies 2) and classified in two sub-types based on varve thickness and clastic content (sub-type $a$ and $b$ ). The differentiation between both sub-types is made at an empiric value of $0.2 \mathrm{~mm}$ (mean plus standard error). Varve thickness variability is mainly controlled by the thickness of the detritus sub-layer.

Microfacies 1a: Organic-diatomaceous varves with an average thickness of $0.15 \mathrm{~mm} \quad(111015-110430$; 108630-105 500; $\quad 101005-97960 ; \quad 96760-94250$; 93 260-92350; $\quad 88905-85780 ; \quad 84670-83120$; $81440-79305 ; 76715-76470$ a). The varve structure is composed of two sub-layers: an organic detritus layer with high organic material content, and another one of diatoms. Varve thickness ranges from 0.1 to $1.8 \mathrm{~mm}$. 

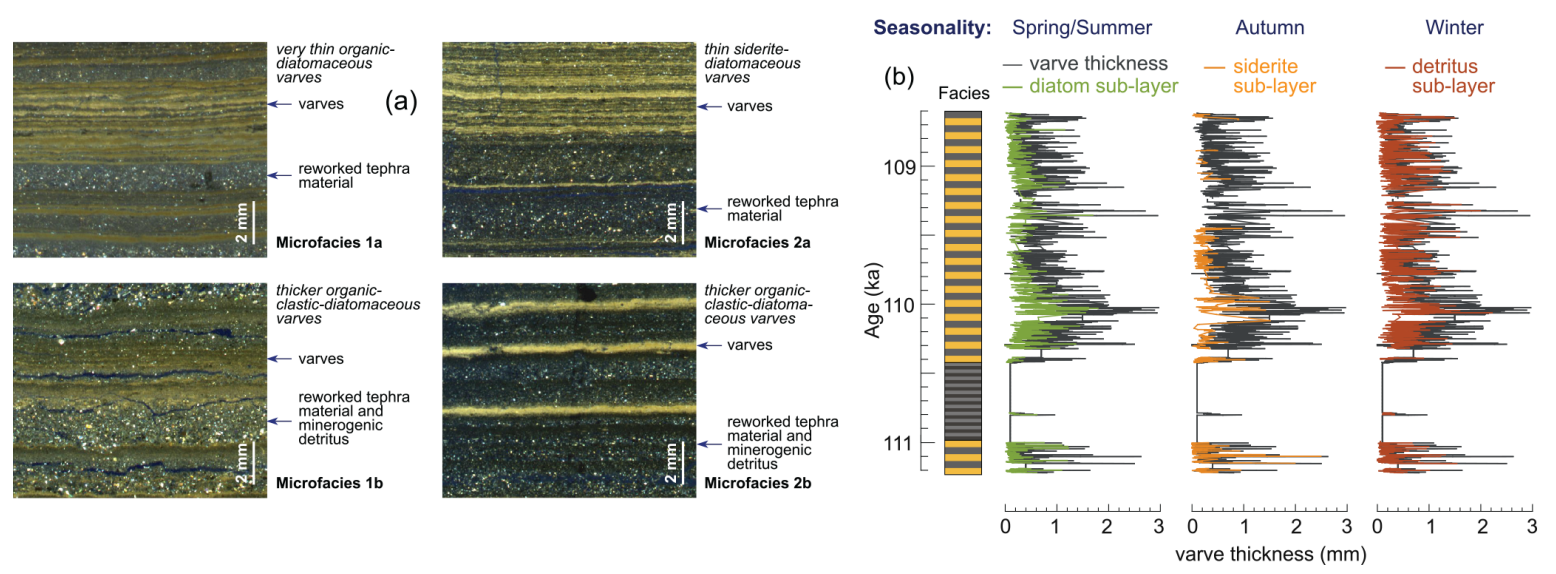

Figure 3. Sedimentological and elemental composition of the varved sediments of Lago Grande di Monticchio: (a) thin section images of the varved sediments of MON showing the different types of microfacies; (b) schematic lithological profile from 111 to $108 \mathrm{ka}$ (microfacies 1a and 2b); total varve thickness (grey) compared with thickness variability of the different sub-layers.

Microfacies $1 b$ : organic-clastic-diatomaceous varves with an average thickness of $0.5 \mathrm{~mm}$ (92070-88905; 79305-76715a). Varve structure is similar to microfacies 1a but the clastic content within the detritus sub-layer is higher. Endogenic carbonate precipitation (calcite or siderite) occasionally occurs in seasonal sub-layers. Varve thickness varies between 0.4 and $2.5 \mathrm{~mm}$. The higher varve thickness compared with microfacies 1a is mainly due to higher clastic content in the winter sub-layer (Fig. 3b).

Microfacies 2a: siderite-diatomaceous varves with an average thickness of $0.17 \mathrm{~mm}$ (103000-101000; 97960-96760; 94250-93260; $\quad 92350-92070$; 85780-84670a). These varves are composed of three laminae: minerogenic detritus, diatoms frustules and authigenic siderite. Varve thickness varies between 0.3 and $2.6 \mathrm{~mm}$.

Microfacies 2b: siderite-clastic-diatomaceous varves with an average thickness of $0.53 \mathrm{~mm}$ (111230-111015; 110430-108630; 105 500-103000; 83 120-81440 a). The varve structure is similar to microfacies $2 \mathrm{a}$ but the clastic content within the detritus sub-layer is higher. Varve thickness varies between 0.5 and $6 \mathrm{~mm}$.

The distribution of the microfacies within the stratigraphic sediment column distinguishes seven stratigraphic units and shows alternations between periods of thinner and thicker varves. Unit 1 (111.2-108.6 ka), unit 3 (92.1-88.9 ka), unit $5(83.1-81.4 \mathrm{ka})$ and unit $7(79.3-76.7 \mathrm{ka})$ are characterized by deposition of microfacies type $b$ (thicker varves) and higher varve thickness variability $(0.3-3 \mathrm{~mm})$. In contrast, in unit $2(108.6-92.1 \mathrm{ka})$, unit $4(88.9-83.1 \mathrm{ka})$ and unit $6(81.4-79.3 \mathrm{ka})$ microfacies type a (thinner varves) and lower inter-annual fluctuation prevail (Fig. 4) with the exception of the interval $105.5-103 \mathrm{ka}$ (microfacies $2 \mathrm{~b}$ ) within unit 2, which shows lightly thicker than average. Additionally, reworked deposits are thicker $(>0.5 \mathrm{~mm})$ in units 1,3 ,
5 and 7 showing an additional detrital input from the catchment during the interval of thicker varves (Fig. 4).

\subsection{Element scanning}

The heterogeneous nature of the MON sediments, i.e. organic-clastic-diatomaceous-siderite varves, reworked tephra material and primary tephra fallout layers, suggests multiple factors controlling the chemical element distribution. Microfacies analyses reveal that changes in the clastic input are the major cause for varve thickness variability in the sediments. Hence, the terrigenous component of the sediments should allow the identification of different environmental processes controlling detrital influx into the lake. The lake catchment is composed of volcanic rocks rich in K-feldspar, foids, Fe-Ti-oxides and other mafic minerals such as pyroxenes, biotites and amphiboles (Zolitschka and Negendank, 1996). Measured element intensities of the Al are very low in comparison with other terrigenous elements such as the $\mathrm{Ti}, \mathrm{K}$ and $\mathrm{Fe}$, but its variability is closely related to the $\mathrm{Ti}$ along the whole sequence (Fig. 5a). The Ti-K scatter plot suggests two different $\mathrm{K}$ sources (Fig. 5b): $\mathrm{K}$ is proportional to $\mathrm{Ti}$ variability for values between 0 and 20000 counts (red ellipse), but shows independent behaviour for higher K-counts (green ellipse). A similar pattern is found for the Ti and the Fe (Fig. 5c, red and yellow ellipse). In contrast, the $\mathrm{Ti}$ and the $\mathrm{Si}$ are only weakly related suggesting different environmental indicators (Fig. 5d).

Figure 4 shows some selected elements plotted against time together with complementary sedimentological information. Variability of $\mathrm{Ti}$ is associated with changes in varve thickness and composition at millennial timescales. Higher Ti-counts occur within thicker varves and clastic intervals (microfacies type b), while low values correspond to thinner organic varves (microfacies type a). Additionally, Ti variability resembles annual fluctuations in varve thickness within 


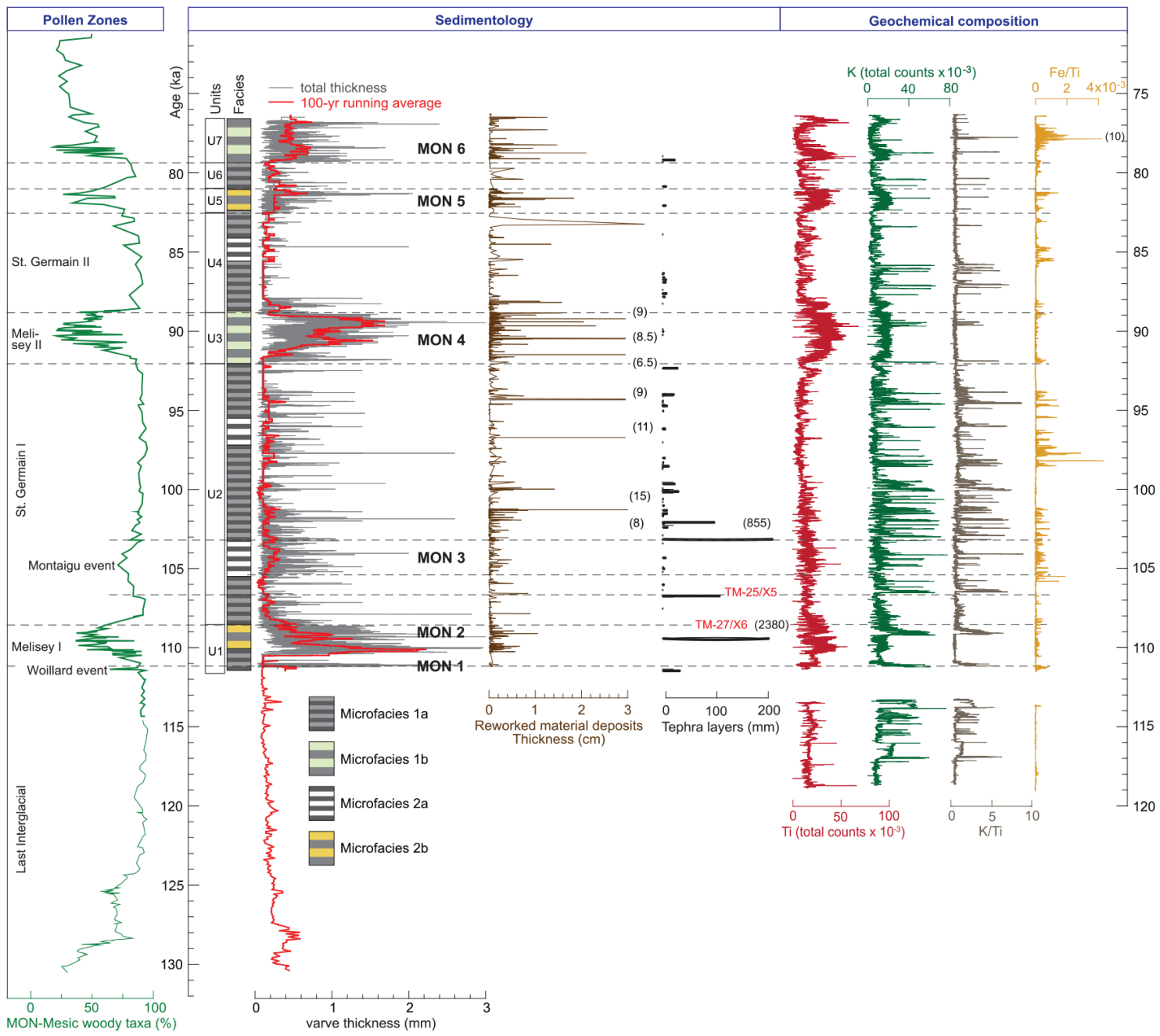

Figure 4. Environmental and climate proxies. From left to right: mesic woody taxa percentages (decadal resolution) on MON-2014 timescales (modified from Brauer et al., 2007) and pollen sub-zones; schematic lithological profile of the study interval; varve thickness variability (grey line) and 100-year average sedimentation rate (red line; data for the interval 112-133 ka have been taken from Brauer et al., 2007); thickness variability reworked material deposits; thickness of the primary tephra layers; distribution of the Ti and K as derived from $\mu$ XRF measurements and the $\mathrm{K} / \mathrm{Ti}$ and $\mathrm{Fe} / \mathrm{Ti}$ ratios throughout the sediment record.

microfacies type b suggesting that Ti-counts are controlled by annual detrital input into the lake. In contrast, the variability of $\mathrm{K}$ is much higher along the entire study interval and does not keep any clear relation with microfacies, varve thickness, reworked deposits or primary tephra layers. $\mathrm{K} / \mathrm{Ti}$ ratios have been plotted in order to distinguish different $\mathrm{K}$ resources. This ratio is well correlated with primary tephra deposition, suggesting that higher $\mathrm{K}$ concentrations in the sediments ( $>20000$ counts, green ellipse in Fig. 5b) correspond to volcanic ash (mainly of K-alkaline composition; Wutke et al., 2014) (Fig. 4). Fe / Ti ratios show the Fe is associated with both siderite varves (microfacies 2 ) and tephra layers (Fig. 4, yellow ellipse in Fig. 5c). The Si / Ti ratio (not shown) was calculated in order to distinguish biogenic silica and siliciclastic detrital matter. Higher values occur during the interval 100-92 ka and 88-76 ka, but this trend does not keep a clear relationship with increasing diatom sub-layer or with reworked deposits. Due to the ambiguous data we avoid using $\mathrm{Si}$ as an environmental or climate proxy in this study.

\section{Millennial- and sub-millennial scale climate variability in Lago Grande di Monticchio}

The palynological zonation defined in central Europe during the early Weichselian/early last glaciation (Woillard, 1978) has been also identified in the MON pollen record, which has a maximum resolution at decadal scale (Fig. 4). The stadial intervals Melisey 1 and 2 and Montaigu events as well as the shorter cold oscillation termed Woillard event are reflected by pollen zones (LPAZ 20, 19b and 18) mainly characterized by decreased temperate Mediterranean woody taxa (Allen et al., 1999; Brauer et al., 2007). According to previ- 

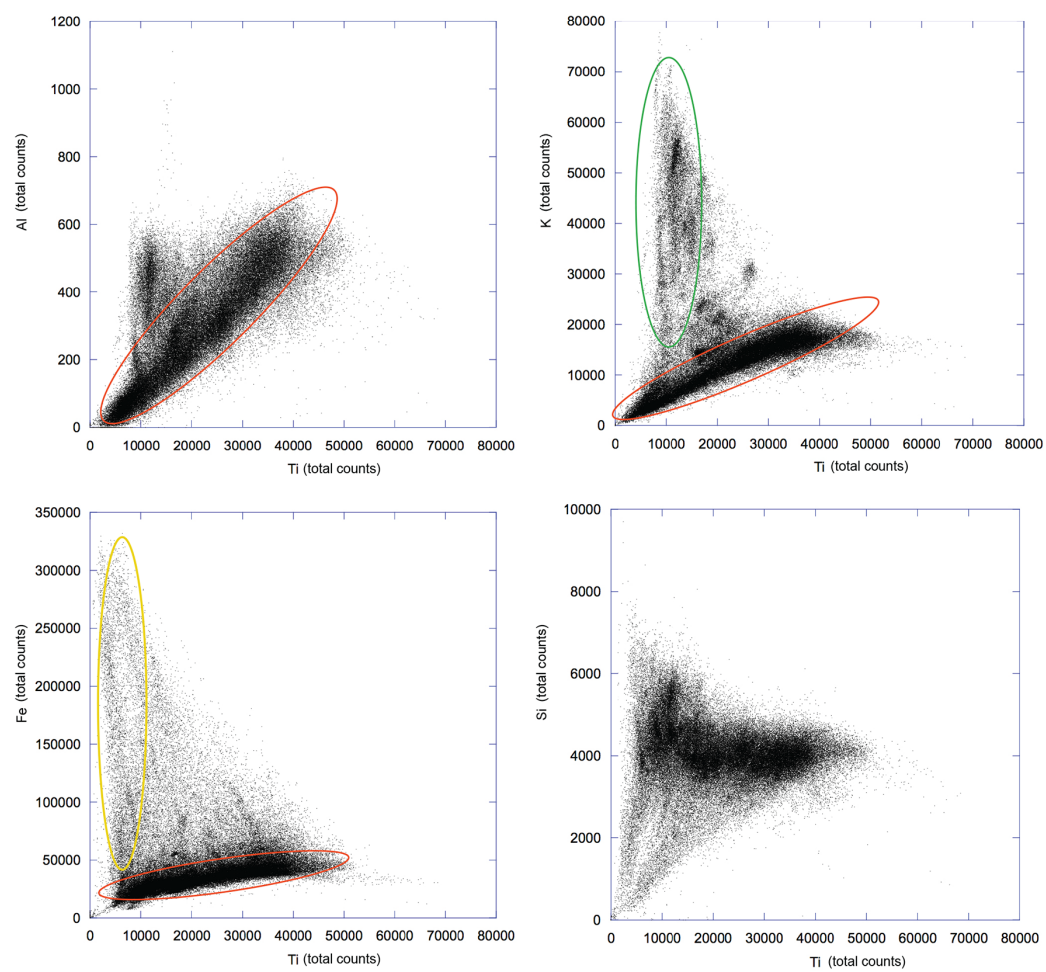

Figure 5. Scatter plots for major terrigenous elements as derived from $\mu$ XRF measurements. Red ellipses indicate the range of values for elements ratios corresponding to the terrigenous component. The green ellipse shows the range $\mathrm{K} / \mathrm{Ti}$ ratio values biased by tephra layers (volcanic ash) and the yellow ellipse marks the range of values of $\mathrm{Fe} / \mathrm{Ti}$ ratio that indicate the presence of siderite precipitation and volcanic ash.

ous climate interpretation of the pollen spectra, these pollen zones represent periods of increased seasonality characterized by more severe cold winters and drier summers than at present (Allen et al., 2000; Allen and Huntley, 2009), which is in good agreement with the stadial conditions described more widely for the Mediterranean (Milner et al., 2013). In contrast, the warm St. Germain 1 and 2 interstadials are dominated in the MON record by mesic woody taxa similar to that during the Holocene (Brauer et al., 2007; Fig. 4).

In the sedimentological and geochemical records, the pollen-defined stadials coincide with intervals of thicker varves and high $\mathrm{Ti}$ intensities (microfacies type b) and are labelled as MON 1-6 (Fig. 4, Table 1). The first four of these intervals coincide with Woillard event, Melisey 1, Montaigu event and Melisey 2 (Brauer et al., 2007) and the two youngest coincide with the Monticchio pollen sub-zone LPAZ 17d and 17b (Allen et al., 1999). As mentioned above, varve thickness is mainly controlled by the thickness of the winter sub-layer (Fig. 3b) and closely related to the clastic influx into the lake as indicated by Ti-counts (Fig. 4). Based on the good correlation between pollen and sedimentological and geochemical data, enhanced detrital matter flux within the stadials is interpreted as a result of increased catchment erosion likely in response to forest depletion. In addition, the higher number of (thicker) discrete deposits (Fig. 4) might re- flect an increased reworking of littoral sediments as a consequence of lake level decreases during the summer droughts. Microfacies analysis reveals that slight increases also in the thickness of diatom sub-layer are related to thicker detrital sub-layers (Fig. 3b), probably because of higher external nutrient input into the lake by stronger soil erosion. A bias of varve thickness by reworked tephra after deposition of thick tephra layers might be only a minor effect since no relationship between thicker tephra deposits and subsequent increase in varve thickness has been observed (Fig. 4). This can be demonstrated, for example, for TM-25, one of the thickest tephra layers in MON. Despite increased K-counts in the ca. 250 varves following the ash deposit indicating some tephra material reworking, there is no significant increase in varve thickness observed (Fig. 4). As a result, we can apply varve thickness as an annual climate proxy (i.e. thicker varves $=$ Mediterranean stadial conditions), which allows us to define the boundaries of the main climatic oscillation more precisely than with the lower-resolution pollen data alone (Fig. 6). In the following we describe the succession of the stadial spells in more detail and in stratigraphical order.

MON 1 (111.23-111.01 ka) lasted $217 \pm 4$ varve yr and the onset and the end of this climatic oscillation occurred within a year (Table 1, Fig. 6). MON 1 corresponds to Woil- 

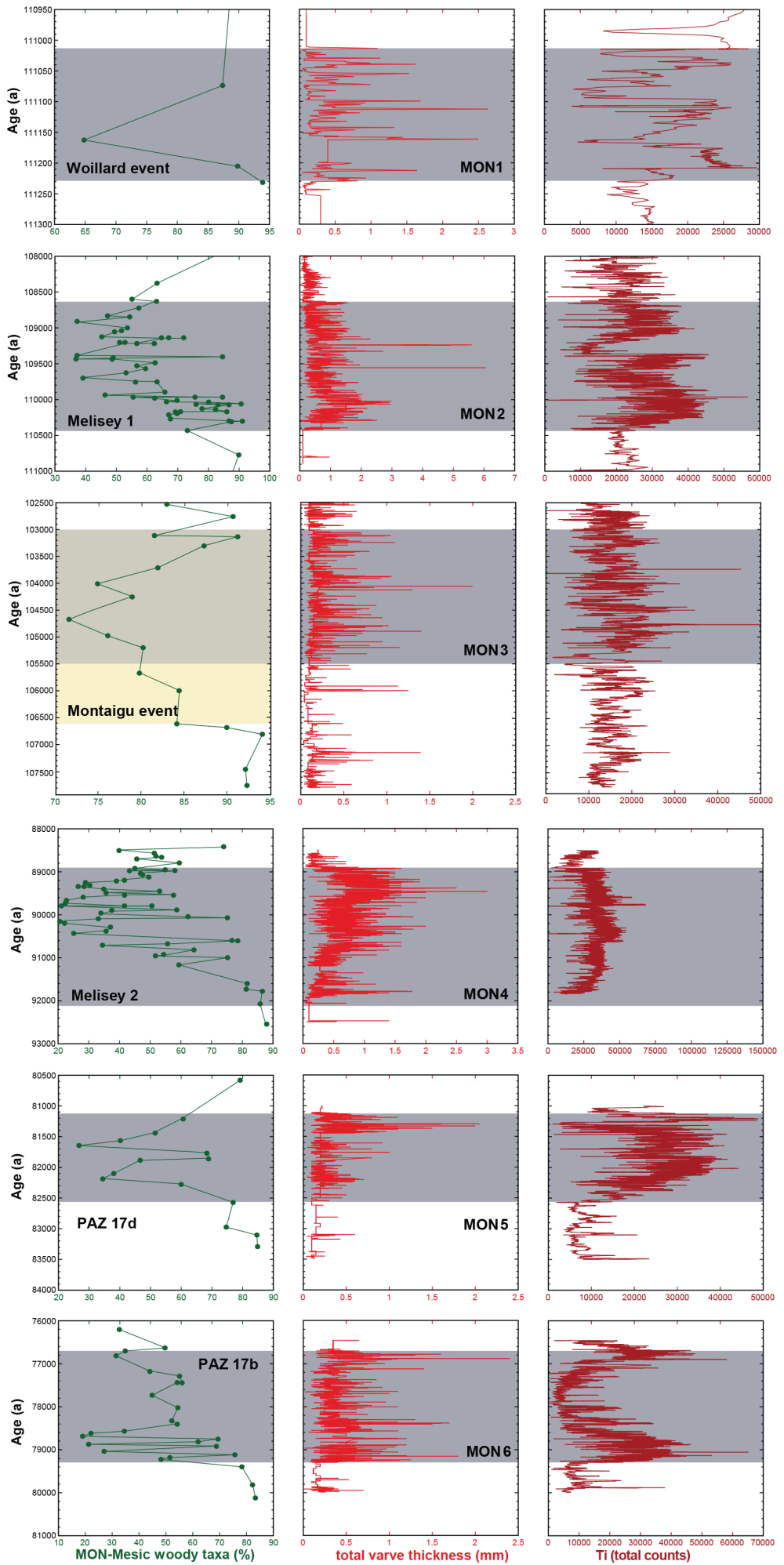

Figure 6. MON-Mesic woody taxa, total varve thickness and Ti-counts zoomed in on the Mediterranean stadials MON 1 to MON 6. Resolution of the pollen samples is shown as green points on the mesic woody curve. 
lard event, which is reflected by four pollen samples indicating vegetation changes within less than 50 years (the limit of pollen data resolution). The duration of MON 1 as given here is about 100 years shorter than the previously published duration of Woillard event as defined by pollen data (Brauer et al., 2007). This is mainly due to the fact that boundaries of this short climatic oscillation could not be precisely captured because of the insufficient resolution of the pollen data (Fig. 6). In addition to the less precise boundary definition in the lower-resolution pollen data, part of the different durations of MON 1 (this study) and the Woillard (Brauer et al., 2007) can be explained by 15 more varves counted in the MON-07 chronology compared to the MON-2014 timescale.

MON $2(110.43-108.63 \mathrm{ka})$ occurred only ca. 600 years after MON 1 but lasted much longer (1798 \pm 69 varves yr). The transitions in the varve data are very sharp and comprise only 7 varves at the onset and 20 varves at the end. However, the pollen boundaries of the corresponding Melisey 1 stadial are sharp only at the onset (ca. 40 varves, i.e. limit of sample resolution), whereas the end occurred gradually over ca. 800 varve yr. Since the upper (biostratigraphic) boundary of Melisey (Brauer et al., 2007) has been defined at the onset of the gradual decrease this period is not included in Melisey 1. Therefore, the duration of MON 2 (1798 varves in MON-2014 counts) and Melisey 1 (1900 varves in MON07 counts) are similar (Table 1, Fig. 6).

The varve signal for MON $3(105.50-103.00 \mathrm{ka})$ is less clear than for the other oscillations and also the transitions are more gradual (Table 1; Fig. 3). Similarly, the decrease of arboreal pollen at that time (Montaigu event) is less pronounced and tree pollen percentages remain at ca. $70 \%$ level, whereas tree pollen decreased down to $\sim 20 \%$ within Melisey 1 and Melisey 2 (Fig. 6; Brauer et al., 2007). Montaigu event in the pollen record is characterized by a slow and gradual forest deterioration (from 93.84 to $71.5 \%$ ) between 106.6 and $104.68 \mathrm{ka}$ and a subsequent recovery (up to $91.14 \%$ ) during the following 1550 varve yr (Fig. 6). The onset of the varve-defined MON 3 interval occurred 1100 varve $y r$ after the start of the pollen change, at $105.5 \mathrm{ka}$. Between the start of the Montiagu event and the onset of MON-3 there are three pollen samples, which indicate gradual forest depletion (Fig. 6). The change in the varve thickness occurs when the woody taxa values cross the border of the $80 \%$ (Fig. 6). In contrast, the end of the Montaigu event (between 103.12 and $102.76 \mathrm{ka}$ ) occurred synchronously with varve changes at the end of MON 3 (103.07 ka) and for this reason the pollen-defined Montaigu event comprises 3600 varve yr compared to the shorter varve-defined MON 3 $(2500 \pm 142$ varve yr; Fig. 6).

MON 4 (92.07-88.91 ka) began ca. 10900 varve yr after the end of MON 3 and started and ended abruptly within a decade. The first phase of MON 4 is characterized by two peaks in varve thickness interrupted by a short interval of thin varves (180 varve yr). The transitions in the corresponding pollen zone Melisey 2 appear slightly more gradual be- cause of the lower sample resolution of ca. 80 varves (Fig. 6). The duration of MON 4 ( $3162 \pm 83$ varve yr) differs from the length of Melisey 2 (2670 varve yr) estimated by the MON2007 chronology (Brauer et al., 2007) because 510 additional varves have been counted in the revised MON-2014 varve counting within the interval between ca. 102.5 and $90.5 \mathrm{ka}$ (see Sect. 4.1). So, the thicker varve interval MON 4 and the pollen interval Melisey 2 are in good agreement on the duration of the climate oscillation.

The two youngest thick varve intervals MON 5 $(82.58-81.12 \mathrm{ka})$ and MON $6(79.31-76.71 \mathrm{ka})$ correspond to periods of decreasing tree pollen and increasing nonarboreal pollen labelled as PAZ $17 \mathrm{~d}$ and $17 \mathrm{~b}$ by Allen et al. (1999). The PAZ 17d started gradually at $83.1 \mathrm{ka}$ with a tree pollen decrease from 87 to $72 \%$ in ca. 600 years. The onset of the MON 5 started abruptly coinciding with a reduction of the mesic woody taxa of $60 \%$ (Fig. 6). The duration of this interval as defined by varve data is $1463 \pm 17$ varve yr (Table 1). MON 6 is located at the top of the studied interval and comprises two centennial-scale oscillations with the first one lasting ca. 400 varve yr coinciding with a rapid decrease in arboreal pollen from 80 to $20 \%$. About 1000 varve yr later tree pollen recovered to ca. $40 \%$ coinciding with a decrease in varve thickness and Ti-counts. The second fluctuation lasted ca. 300 varve yr, ca. 1000 varve yr after the first one. This interval is marked by an abrupt increase in Ti-counts and varve thickness, as well as a reduction in tree pollen to $35 \%$. The following recovery of tree vegetation after MON 6 did not reach values above $45 \%$, suggesting a major shift of the environment from an interglacial to the glacial mode (MIS 5a/4 transition).

In summary, changes in vegetation coincide, within the limit of pollen data resolution ( $>50$ varve yr), with those five oscillations that are characterized by rapid transitions and distinct proxy responses - MON 1 and 2 and MON 4 to 6 . MON 3 is the only climate oscillation where the sediments responded with a time lag to the vegetation change and where the transitions occurred gradually. We could consider that the threshold for the onset of significant erosion is delayed because either the environment could adapt to the decrease in trees (e.g. through dense herb and brush vegetation) or due to the still remaining tree vegetation (up to $80 \%$ ) since the drop was not that strong. In addition, both MON 3 and Montaigu event exhibit the lowest amplitudes of proxy changes of all investigated oscillations. This is in good agreement with the pollen signal in La Grande Pile (Woillard, 1978) where the percentage of the arboreal pollen during the Montaigu event is of $70 \%$, but decreased up to 35 and $30 \%$ within the Melisey 1 and Melisey 2, respectively. Also in the NW Iberian margin, the Montiagu event is less pronounced (Sánchez-Goñi et al., 2005) and the North Atlantic cold pulse $\mathrm{C} 23$, which was correlated with the Montaigu event, was warmer than C 24 (Melisey 1) and C 22 (Melisey 2) (McManus et al., 1994). In contrast, the strongest signals in pollen data (i.e. reduction of tree pollen) are ob- 


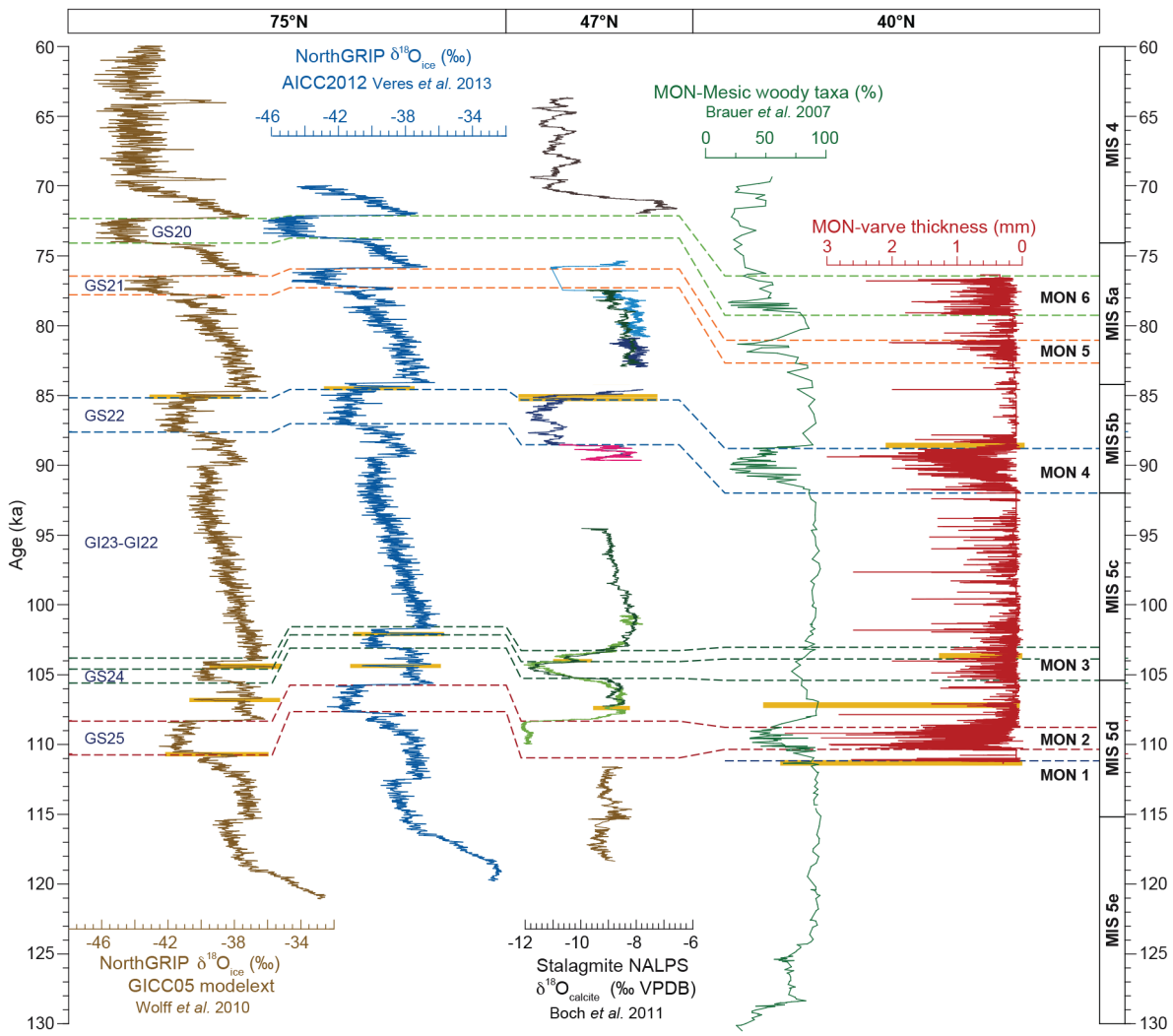

Figure 7. MON varve thickness and pollen record compared to the $\delta^{18} \mathrm{O}_{\text {ice }}$ NorthGRIP record in both GICC05 modelext and AICC2012 timescales, NALPS record, covering a NW-SE transect from 75 to $40^{\circ} \mathrm{N}$ in western Europe. Marine isotope-5 sub-stages (MIS) start dates according to Wright (2000) and Greenland stadials (GS) identified in the $\delta^{18} \mathrm{O}_{\text {ice }}$ NorthGRIP and $\delta^{18} \mathrm{O}_{\text {calcite }}$ NALPS records are shown for comparison. Dashed lines indicate the boundaries of the MON oscillations and their correlatives GS. Duration of the GS is derived from Veres et al. (2013). The short-lived events within GS-24 and GS-22 are not included in the GI and GS duration estimates. Climate changes superimposed to millennial-scale variability are highlighted by the yellow rectangles.

served for the younger cold intervals (Melisey 2, PAZ 17d, PAZ 17b) occurring after ca. $92 \mathrm{ka}$, whereas the most pronounced varve changes occur for the earliest cold oscillations MON 1 and MON 2 at the end of the last interglacial, as well as for MON 4. Hence, the longest cold oscillation MON 4/Melisey 2 (3162 varve yr) is the only interval with a strong signal observed in both data sets. Interestingly, MON 2 and MON 4 are within the MIS $5 \mathrm{~b}$ and 5b, respectively, while MON 3 (weaker signal) started at the boundary between MIS $5 \mathrm{~b}$ and $5 \mathrm{c}$. These observations agree with previous studies which suggest that millennial-scale shifts in vegetation cover in the Mediterranean is greatest during intermediate ice volume states through the effect of ice sheet size and configuration on temperature and precipitation patterns in southern Europe (Tzedakis, 2005; Margari et al., 2010).

\section{Comparison to the NorthGRIP and NALPS isotope records}

\subsection{Duration of the cold spells along the transect from Greenland to the Mediterranean}

The new annual sedimentological data in combination with the previously published pollen record and the independently established chronology allows detailed high-resolutioncomparison of the MON $\left(40^{\circ} \mathrm{N}\right)$ sediment record along a NW-SE transect across western Europe including the high-resolution $\delta^{18} \mathrm{O}_{\text {calcite }}$ NALPS stalagmite (Boch et al., 2011) from the Austrian Alps $\left(47^{\circ} \mathrm{N}\right)$ and $\delta^{18} \mathrm{O}_{\text {ice }}$ NorthGRIP ice core $\left(75^{\circ} \mathrm{N}\right)$ in order to investigate similarities and differences between these key climate archives (Fig. 7). The $\delta^{18} \mathrm{O}_{\text {ice }}$ NorthGRIP record is displayed both on the updated GICC05 modelext (Wolff et al., 2010) and the AICC2012 timescales (Bazin et al., 2013; Veres et al., 2013). Our comparisons are based on visual inspections of major abrupt changes in the different proxy data on their own independently established chronologies with inherent 
Table 2. Duration of the millennial-scale climatic oscillations (stadial and interstadials) in the four different independent chronologies from Greenland to the Mediterranean. NorthGRIP $\delta^{18} \mathrm{O}_{\text {ice }}$ as constrained on GICC05 modelext chronology (Wolff et al., 2010) and AICC2012 timescale (Veres et al., 2013); NALPS composite speleothem $\delta^{18} \mathrm{O}$ record (Boch et al., 2011); and MON varve thickness record (this study). The gradual transition from GI23 to GS23 in the NorthNGRIP $\delta^{18} \mathrm{O}_{\text {ice }}$ (rather than the usual sharp decrease) makes it difficult to define a clear boundary between these two periods, so the durations of GI 23 and GS 23 are shown together.

\begin{tabular}{lrrll}
\hline Climatic oscillation & GICC05 modelext $_{\text {(yr) }}$ & AICC2012 (yr) & NALPS (yr) & MON (varve yr) \\
\hline GI20 & 2340 & 2166 & & $2133 \pm 25$ \\
GS21 (MON 5) & 1320 & 1340 & $1720 \pm 384$ & $1463 \pm 17$ \\
GI21 & 7000 & 7009 & $7450 \pm 475$ & $5786 \pm 135$ \\
GS22 (MON 4) & 2620 & 2760 & $3250 \pm 526$ & $3162 \pm 83$ \\
GI23 + GS23 & 14000 & 12512 & - & $10931 \pm 236$ \\
GS24 (MON 3) & 920 & 950 & $1040 \pm 585$ & $2500 \pm 142$ \\
GI24 & 2840 & 2650 & $3090 \pm 636$ & $3131 \pm 344$ \\
GS25 (MON 2) & 2360 & 1990 & & $1798 \pm 69$ \\
\hline
\end{tabular}

uncertainties. Since we do not presume synchronicity between climate change in the different regions and different proxy responses, we explicitly omit from shifting either of the chronologies in order to match them together. This is because we have to consider that the lake sediment proxies may respond differently to climate change than stable isotopes in stalagmites and ice cores, which in turn also might record different climate-related processes. In addition, studies of abrupt climate changes within periods with robust age control like the Younger Dryas revealed regional leads and lags in the range of several decades (Lane et al., 2013; Rach et al., 2014). However, the uncertainties of the chronologies for the early last glaciation (Veres et al., 2013) discussed here prevent us from resolving and discussing potential leads and lags in this short time range. Nevertheless, despite the chronological limitations, the high-resolution data of the records compared here allow a very detailed view from different regional and proxy perspectives particularly on the succession and evolution of cold climatic fluctuations that occurred during the approximately $35 \mathrm{kyr}$ long period between full interglacial and a full glacial mode. In order to circumvent problems due to discrepancies in absolute ages we preferably compare the duration of the cold oscillations and especially the amplitudes and structure of proxy changes.

The first cold oscillation in the MON record (MON 1) occurred after several millennia of rather stable interglacial climate and was the shortest and lasted only $217 \pm 4$ varve yr (Table 1). MON 1 corresponds to the Woillard event defined in the Grande Pile pollen stratigraphy in the French Vosges mountains (Woillard, 1978), but no counterpart is identified in the water isotopic profile from NorthGRIP. In contrast, the short warming at the very end of GI 25 also known as "GI 25 rebound" might be reflected in the MON record as the $600 \mathrm{yr}$ long thinner varve interval between MON 1 and MON 2 (Fig. 7). The NALPS record exhibits an interruption of speleothem growth at the end of the interglacial so that a comparison with MON 1 is not possible. MON 1 is assumed to further correlate with the North Atlantic cold event C25

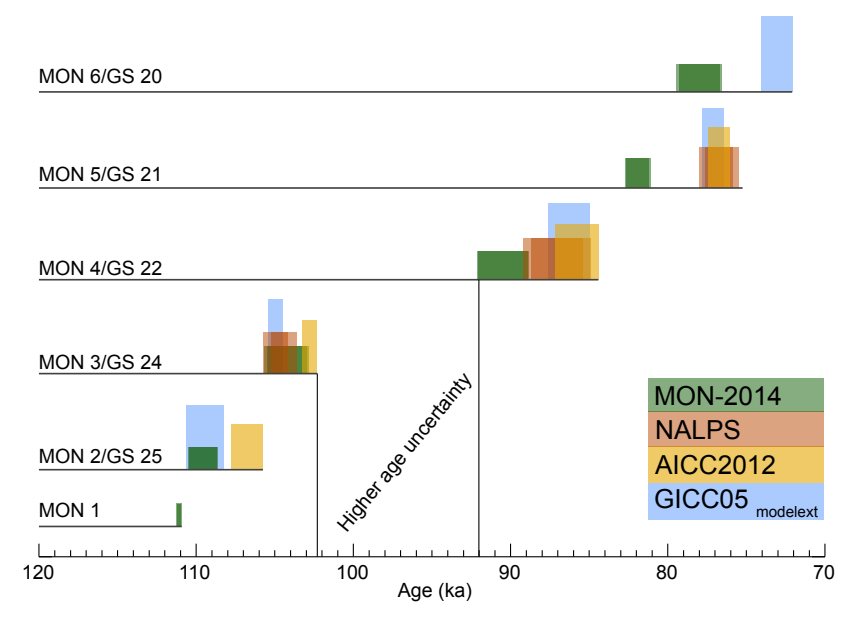

Figure 8. Comparison of the timing and duration of the stadials GS 25 to GS 20 and MON 1 to MON 6 in the North Atlantic and European region as displayed by the different independent chronologies: GICC05 ${ }_{\text {modelext }}$, AICC2012, NALPS and MON-2014.

at the MIS 5e/d transition (Chapman and Shackleton, 1999). Both MON 1 and C25 marked the onset of the recurrent rapid cold spells during MIS 5d-a after stable MIS 5e conditions (Chapman and Shackleton, 1999).

The second cold spell MON 2 (Melisey 1) is assumed to correlate with GS 25 . It is a very distinct oscillation in both the MON and the NorthGRIP record but only partly recorded in NALPS because of a hiatus (Boch et al., 2011). One could imagine that the cessation of stalagmite growth during the first phase of this cold spell was the response to this cooling. The length of MON $2(1798 \pm 69$ varve $y r)$ resembles better the duration of GS 25 on the AICC2012 timescale (1990 years) than on the GICC05 modelext chronology (2360 years) (Fig. 8).

The third cold spell in the MON record (MON 3) broadly correlates with GS 24 in NorthGRIP and in NALPS (Figs. 7, 8). However, the weak signal and gradual transitions in the 
Table 3. Absolute dating of the millennial-scale climate transitions in the four different independent timescales from Greenland to the Mediterranean. NorthGRIP $\delta^{18} \mathrm{O}_{\text {ice }}$ as constrained on GICC05 modelext chronology (Wolff et al., 2010) and AICC2012 timescale (Veres et al., 2013); NALPS composite speleothem $\delta^{18} \mathrm{O}$ record (Boch et al., 2011); and MON varve thickness record, including the $\pm 5 \%$ counting error (this study).

\begin{tabular}{|c|c|c|c|c|}
\hline Climatic oscillation & GICC $05_{\text {modelext }}$ (a) & AICC2012 (a) & NALPS (a) & MON (a) \\
\hline GI19 & 72090 & & $71690 \pm 220$ & $76715 \pm 3835$ \\
\hline GS20 (MON 6) & 74070 & 73896 & & $79260 \pm 3963$ \\
\hline GI20 & 76410 & 76062 & $75860 \pm 300$ & $81120 \pm 4056$ \\
\hline GS21 (MON 5) & 77795 & 77402 & $77580 \pm 240$ & $82583 \pm 4129$ \\
\hline GI21 & 84730 & 84411 & $85030 \pm 410$ & $88905 \pm 4445$ \\
\hline GS22 (MON 4) & 87630 & 87171 & $88690 \pm 330$ & $92070 \pm 4603$ \\
\hline GI23 & 103995 & 102150 & $103550 \pm 375$ & $103000 \pm 5150$ \\
\hline GS24 (MON 3) & 105410 & 103100 & $105210 \pm 450$ & $105500 \pm 5275$ \\
\hline GI24 & 108250 & 105750 & $108300 \pm 450$ & $108630 \pm 5431$ \\
\hline GS25 (MON 2) & 110620 & 107740 & & $110430 \pm 5521$ \\
\hline
\end{tabular}

MON proxies and the differences between pollen and sediment signals make it difficult to define sharp and unequivocal boundaries for this oscillation in the MON record. The longer duration of MON $3(2500 \pm 171$ varve yr) compared to GS 24 in AICC2012 (950 years; Veres et al., 2013), GICC05 $5_{\text {modelext }}$ (920 years; Wolff et al., 2010) and NALPS (1040 \pm 585 years; Boch et al., 2011) (Table 2; Fig. 8) can be explained by differences in boundary definition and, more specifically, by the occurrence of several short-lived variations in varve thickness which are included in MON 3 (Fig. 7). These fluctuations seem to resemble the short warming (precursor GI 23) and subsequent cooling events preceding GI 23 in the NorthGRIP and NALPS records (Fig. 7), which, however, are not included in the duration of GS 24 (Capron et al., 2010; Boch et al., 2011).

MON 4 (Melisey 2) correlates with GS 22. The duration of GS 22 is still under discussion and varies in different ice core chronologies between 2480 years (GICC05 modelext), 2620 years (revised GICC05 modelext timescale; Vallelonga et al., 2012) and 2760 years (AICC2012; Veres et al., 2013). All ages suggest a shorter duration than determined in the NALPS record ( $3250 \pm 526$ varve yr), which in turn is in good agreement with the Monticchio estimate of MON 4 (3162 \pm 51 varve yr; Table 2; Fig. 8). Two phases of reduced varve thickness occurring during 500 years after MON 4 (not included in MON 4) might correlate with two short-lived warming events (precursor GI 21 I and II) at the onset of GI 21 (Boch et el., 2011) (Fig. 7).

MON 5 and 6 are assumed to correlate with GS21 and GS20, respectively. The length of MON 5 $(1463 \pm 149$ varve $y r)$ is in very good agreement with the duration of GS 21 in NALPS (1720 \pm 384 years) but ca. 350 years longer than determined by the ice core chronology (Table 2). Similarly, MON 6 (2590 years), also is 340 years longer than GS 20 in Greenland (Fig. 8). In the NALPS record a cold phase correlating with MON 6 is not recorded due to growth cessation of the stalagmites.

\subsection{Absolute dating implications}

Millennial-scale climatic fluctuations identified in the MON varved record are in broad agreement with Alpine stalagmites and Greenland ice cores, although absolute dating still reveals differences. The MON-2014 chronology is in good agreement with the GICC $05_{\text {modelext }}$ timescale for the three older oscillations MON 1 to MON 3 occurring before $100 \mathrm{ka}$, while the AICC2012 timescale reveals younger ages for this interval mainly because of a shorter duration estimated for the GI 23-GI 22 interstadial. For the younger oscillations (MON 4 to MON 6) occurring after $100 \mathrm{ka}$ the ice core and NALPS chronologies show quite good agreement, while the Monticchio chronology suggests consistently 3500 years older ages (Figs. 7, 8). This difference appears due to the shorter duration revealed for the interstadial interval between MON 3 and MON 4 (9500 years) compared to the durations determined for the corresponding GI 23-GI 22 period in both Greenland chronologies (14000 years in GICC05 modelext; 12500 in AICC2012; Table 3; Figs. 7, 8). Even if the ca. 3500 varve $\mathrm{yr}$ older ages provided by the MON-2014 timescale are still within the gross $\pm 5 \%$ error range for the absolute ages, we tend to assume a so far undetected additional error (hiatus?) of our varve chronology located in the interval between MON 3 and MON 4, although we did not find any conspicuous sediment structure even through detailed thin section analyses. A possible problem in this part of the varve chronology, however, is further suggested by the kink in the sedimentation rate curve and the discrepancy between the varve ages and tephra ages between ca. 106 and $96 \mathrm{ka}$ (between MON 3 and MON 4) shown in Fig. 2c and $\mathrm{d}$ (see Sect. 4.1). Intriguingly, this is also the time interval where the discrepancies between both ice core chronologies is largest and the NALPS record shows a discontinuity of ca. 5000 years (Figs. 7 and 8 ). 


\section{Conclusions}

Intervals of thicker varves and high Ti-counts identified in the sediment record of Lago Grande di Monticchio resemble both millennial- and sub-millennial-scale abrupt climatic changes during the early stage of the last glaciation. Six major oscillations in varve sedimentation (MON 1-6) can be identified between 76 and $112 \mathrm{ka}$, which coincide with Mediterranean stadial spells (cold winter/dry summer) as derived from the Monticchio pollen record. The annual resolution of the sediment proxies allows (1) a more precise definition of these cold intervals, and (2) deciphering the velocity of change at the transitions. This new data set also provides the opportunity to precisely compare, the Mediterranean response to abrupt climate changes with those recorded in Greenland and northern Alps despite the remaining age uncertainties. The oscillations MON 2-6 are assumed to correlate with GS 25-20, respectively. Regional similarities and differences in amplitude of proxy responses and the durations of the climatic oscillations have been found:

- MON 1, the first clear signal of cooling seen in the Mediterranean, has no counterpart in the NorthGRIP record but coincides with the lowest values at the end of the stepwise isotope change during the second half of GI 25.

- MON 2 (GS 25) and MON 4 (GS 22) were the longest millennial-scale cold intervals in all records with durations between 1850 and 2360 years (MON 2, GS 25) and between 2620 and 3250 years (MON 4, GS 22).

- The largest difference between the Monticchio varve data and Greenland and speleothem isotopes is observed for MON 3. This is the least pronounced cold spell of all Monticchio oscillations, in both the varved and the pollen records, and is characterized by gradual transitions. The corresponding GS 24 in NorthGRIP is also the least pronounced stadial in the studied time interval, although still more distinct than MON 3. The corresponding oscillation in the NALPS record, in contrast, is very pronounced and shows a ca. $2 \%$ o decrease in $\delta^{18} \mathrm{O}_{\text {calcite. }}$ Lower-resolution marine- and terrestrial records in the North Atlantic and European region also reflect weaker signal for the climate oscillation correlated with the GS 24. Explanations for the attenuated response to the climate change in the Mediterranean at that time remain elusive so far, but one might speculate about a possible link to its occurrence during a period of lower global ice volume (MIS 5c).

- The coldest episodes in Greenland were GS 21 and GS 20, which already reached the level of full glacial isotope values (ca. $-44 \%$ of $\delta^{18} \mathrm{O}_{\text {ice }}$ ). Excluding GS 24, there is a general increasing trend in the amplitude of the stadials in NorthGRIP from GS 25 to 20.
A similar trend is seen in the MON pollen record but not as distinct as in the ice core. The growth cessation of the stalagmites in the northern Alps during GS 21 and GS 20 might also support cooler stadials at the end of the MIS 5. In contrast, in the Monticchio record the most pronounced cold spells are MON 2 and MON 4, suggesting larger environmental impacts in the Mediterranean coinciding with the stages of higher global ice volume MIS 5d and MIS 5b, respectively.

Millennial- and sub-millennial-scale climate variability occurring during the early phase of the last glaciation are in broad agreement between Greenland, the Alps and the central Mediterranean. However, there are differences between records that require further investigations in terms of (i) proxy response, and (ii) regionally different expression of climate change.

Acknowledgements. We thank D. Berger, M. Köhler, M. Prena, R. Scheuss, S. Opitz and D. Axel for the retrieval of sediment cores during the coring campaign in 2000. Special thanks are due to G. Arnold, M. Köhler and D. Berger for thin-section preparation, A. Hendrich for graphical support and Jens Mingram and Christoph Spötl for comments and suggestions on a previous version of the paper. Also to W. Fletcher and an anonymous referee for their constructive comments and suggestions on the paper. This study was funded by the GFZ German Research Centre for Geosciences, Potsdam, Germany, and is a contribution to the Helmholtz-Association climate initiative REKLIM (Topic 8 "Rapid Climate Change from Proxy data”).

Data supplement available at: doi:10.1594/PANGAEA.837248.

The service charges for this open access publication have been covered by a Research Centre of the Helmholtz Association.

Edited by: E. McClymont

\section{References}

Allen, J. R. M. and Huntley, B.: Last Interglacial palaeovegetation, palaeoenvironments and chronology: a new record from Lago Grande di Monticchio, southern Italy, Quaternary Sci. Rev., 28, 1521-1538, 2009.

Allen, J. R. M., Brandt, U., Brauer, A., Hubberten, H., Huntley, B., Kraml, M., Mackensen, A., Mingram, J., Negendank, È. F. W., Nowaczyk, N. R., Watts, W. A., Wulf, S., and Zolitschka, B.: Rapid environmental changes in southern Europe during the last glacial period, Nature, 400, 740-743, 1999.

Allen, J. R. M., Watts, W. A., and Huntley, B.: Weichselian palynostratigraphy, palaeovegetation and palaeoenvironment; the record from Lago Grande di Monticchio, souther Italy, Quatern. Int., 73/74, 91-110, 2000.

Bazin, L., Landais, A., Lemieux-Dudon, B., Toyé Mahamadou Kele, H., Veres, D., Parrenin, F., Martinerie, P., Ritz, C., Capron, 
E., Lipenkov, V., Loutre, M.-F., Raynaud, D., Vinther, B., Svensson, A., Rasmussen, S. O., Severi, M., Blunier, T., Leuenberger, M., Fischer, H., Masson-Delmotte, V., Chappellaz, J., and Wolff, E.: An optimized multi-proxy, multi-site Antarctic ice and gas orbital chronology (AICC2012): 120-800 ka, Clim. Past, 9, 1715-1731, doi:10.5194/cp-9-1715-2013, 2013.

Boch, R., Cheng, H., Spötl, C., Edwards, R. L., Wang, X., and Häuselmann, Ph.: NALPS: a precisely dated European climate record 120-60 ka, Clim. Past, 7, 1247-1259, doi:10.5194/cp-71247-2011, 2011.

Brauer, A., Mingram, J., Frank, U., Gu, C., Schettler, G., Wulf, S., Zolitschka, B., and Negendank, K. F. W.: Abrupt environmental oscillations during the Early Weichselian recorded at Lago Grande di Monticchio, southern Italy, Quatern. Int., 74, 79-90, 2000

Brauer, A., Allen, J. R. M., Mingram, J., Dulski, P., Wulf, S., and Huntley, B.: Evidence for last interglacial chronology and environmental change from Southern Europe, P. Natl. Acad. Sci. USA, 104, 450-455, 2007.

Brocchini, D., La Volpe, L., Laurenzi, M. A., and Principe, C.: Storia evolutiva del Monte Vulture, Plinius, 12, 22-25, 1994.

Capron, E., Landais, A., Chappellaz, J., Schilt, A., Buiron, D., Dahl-Jensen, D., Johnsen, S. J., Jouzel, J., Lemieux-Dudon, B., Loulergue, L., Leuenberger, M., Masson-Delmotte, V., Meyer, H., Oerter, H., and Stenni, B.: Millennial and sub-millennial scale climatic variations recorded in polar ice cores over the last glacial period, Clim. Past, 6, 345-365, doi:10.5194/cp-6-3452010, 2010.

Chapman, M. R. and Shackleton, N. J.: Global ice-volume fluctuations, North Atlantic ice-rafting events , and deep-ocean circulation changes between 130 and 70 ka, Geology, 27, 795-798, 1999.

Dansgaard, W., Johnsen, S. J., Clausen, H. B., Dahl-Jensen, D., Gundestrup, N. S., Hammer, C. U., Hvidberg, C. S., Steffensen, J. P., Svelnbjörnsdottir, A. E., Jouzel, J., and Bond, G.: Evidence for general instability of past climate from a $250-\mathrm{kyr}$ ice-core record, Nature, 364, 218-221, 1993.

Drysdale, R. N., Zanchetta, G., Hellstrom, J. C., Fallick, A. E., McDonald, J., and Cartwright, I.: Stalagmite evidence for the precise timing of North Atlantic cold events during the early last glacial, Geology, 35, 77-80, 2007.

Giaccio, B., Nomade, S., Wulf, S., Isaia, R., Sottili, G., Cavuoto, G., Galli, P., Messina, P., Sposato, A., Sulpizio, R., and Zanchetta, G.: The late MIS 5 Mediterranean tephra markers: a reappraisal from peninsular Italy terrestrial records, Quaternary Sci. Rev., 56, 31-45, 2012.

Gillot, P.-Y. and Keller, J.: Radiochronological dating of Stromboli, Acta Vulcanologica, 3, 69-77, 1993.

Hieke Merlin, O.: I prodotti vulcanici del Monte Vulture. Memorie degli istituti di geologia e Mineralogia dell'Università di Padova XXVI, 1-65, 1967.

Iorio, M., Liddicoat, J., Budillon, F., Incoronato, A., Coe, R. S., Insinga, D. D., Cassata, W. S., Lubritto, C., Angelino, A., and Tamburrino, S.: Combined palaeomagnetic secular variation and petrophysical records to time-constrain geological and hazardous events: An example from the eastern Tyrrhenian Sea over the last $120 \mathrm{ka}$, Glob. Planet. Change, 113, 91-109, 2014.

Kukla, G.: How long and how stable was the last interglacial?, Quaternary Sci. Rev., 16, 605-612, 1997.
Lane, C., Brauer, A., Blockley, S. P. E., and Dulski, P.: Volcanic ash reveals time-transgressive abrupt climate change during the Younger Dryas, Geology, 41, 1251-1254, doi:10.1130/G34867.1, 2013.

Mangerud, J., Dokken, T., Hebbeln, D., Heggen, B., Ingolfsson, O., Landvik, J. Y., Mejdahl, V., Svendsen, J. I., and Vorren, T. O.: Fluctuations of the Svalbard-Barents Sea ice-sheet during the last 150000 years, Quaternary Sci. Rev., 17, 11-42, 1998.

Margari, V., Skinner, L. C., Tzedakis, P. C., Ganapolski, A., Vautravers, M., and Shackleton, N. J.: The nature of millennialscale climate variability during the past two glacial periods, Nat. Geosci., 3, 127-131, 2010.

McManus, J. F., Bond, G. C., Broecker, W. S., Johnsen, S., Labeyrie, L., and Higgins, S.: High-resolution climate records from the North Atlantic during the last interglacial, Nature, 371, 326-329, 1994.

Milner, A. M., Müller, U. C., Roucoux, K. H., Collier, R. E. L., Pross, J., Kalaitzidis, S., Christanis, K., and Tzedakis, P. C.: Environmental variability during the Last Interglacial: a new highresolution pollen record from Tenaghi Philippon, Greece, J. Quaternary Sci., 28, 113-117, 2013.

Narcisi, B.: Tephrochronology of a late quatternary lacustrine record from the monticchio maar (vulture volcano, southern Italy), Quaternary Sci. Rev., 15, 155-165, 1996.

NorthNGRIP project memebers: High-resolution record of Northern Hemisphere climate extending into the last interglacial period, Nature, 431, 147-151, 2004.

Rach, O., Brauer, A., Wilkes, H., and Sachse, D.: Delayed hydrological response to Greenland coling at the onset of the Younger Dryas in western Europe, Nat. Geosci., 7, 109-112, 2014.

Rotolo, S. G., Scaillet, S., La Felice, S., and Vita-Scaillet, G.: A revision of the structure and stratigraphy of pre-Green Tuff ignimbrites at Pantelleria (Strait of Sicily), J. Volcanol. Geoth. Res., 250, 61-74, 2013.

Sánchez Goñi, M. F., Eynaud, F., Turon, J. L., and Shackleton, N. J.: High resolution palynological record off the Iberian margin: direct land-sea correlation for the Last Interglacial complex, Earth Planet. Sc. Lett., 171, 123-137, 1999.

Sánchez Goñi, M. F., Loutre, M. F., Crucifix, M., Peyron, O., Santos, L., Duprat, J., Malaizé, B., Turon, J. L., and Peypouquet, J. P.: Increasing vegetation and climate gradient in Western Europe over the Last Glacial Inception (122-110 ka): data-model comparison, Earth Planet. Sc. Lett., 231, 111-130, 2005.

Shackleton, N. J.: Oxygen isotopes, ice volume and sea level, Quaternary Sci. Rev., 6, 183-190, 1987.

Shackleton, N. J., Chapman, M., Sánchez-Goñi, M. F., Pailler, D., and Lancelot, Y.: The Classic Marine Isotope Substage 5e, Quaternary Res., 58, 14-16, 2002.

Stoppa, F. and Principe, C.: Erratum to "Eruption style and petrology of a new carbonatitic suite from the Mt. Vulture (Southern Italy): The Monticchio Lakes Formation” [Journal of Volcanology and Geothermal Research 78 (1997) 251-265], J. Volcanol. Geoth. Res., 80, 137-153, 1998.

Tzedakis, P. C.: Toward an understanding of the response of southern European vegetation to orbital and suborbital climate variability, Quaternary Sci. Rev., 24, 1585-1599, 2005.

Vallelonga, P., Bertagna, G., Blunier, T., Kjær, H. A., Popp, T. J., Rasmussen, S. O., Steffensen, J. P., Stowasser, C., Svensson, A. S., Warming, E., Winstrup, M., Bigler, M., and Kipfstuhl, S.: Du- 
ration of Greenland Stadial 22 and ice-gas $\Delta$ age from counting of annual layers in Greenland NGRIP ice core, Clim. Past, 8, 1839-1847, doi:10.5194/cp-8-1839-2012, 2012.

Veres, D., Bazin, L., Landais, A., Toyé Mahamadou Kele, H., Lemieux-Dudon, B., Parrenin, F., Martinerie, P., Blayo, E., Blunier, T., Capron, E., Chappellaz, J., Rasmussen, S. O., Severi, M., Svensson, A., Vinther, B., and Wolff, E. W.: The Antarctic ice core chronology (AICC2012): an optimized multi-parameter and multi-site dating approach for the last 120 thousand years, Clim. Past, 9, 1733-1748, doi:10.5194/cp-9-1733-2013, 2013.

Watts, W.: Vegetation history and palaeoclimate of the last glacial period of Lago Grande di Monticchio, southern Italy, Quaternary Sci. Rev., 15, 133-153, 1996.

Woillard, G. M.: Grande Pile peat bog: A continuous pollen record for the last 140,000 years, Quaternary Res., 9, 1-21, 1978.

Wolff, E. W., Chappellaz, J., Blunier, T., Rasmussen, S. O., and Svensson, A.: Millennial-scale variability during the last glacial: The ice core record, Quaternary Sci. Rev., 29, 2828-2838, 2010.

Wright, J. D.: Global Climate Change in Marine Stable Isotope Record, in: Quaternary Geochronology: Methods and Applications, edited by: Noller, J. S., Sowers, J. M., and Lettis, W. R., American Geophysical Union, 427-433, 2000.
Wulf, S., Kraml, M., Brauer, A., Keller, J., and Negendank, J. F. W.: Tephrochronology of the $100 \mathrm{ka}$ lacustrine sediment record of Lago Grande di Monticchio (southern Italy), Quatern. Int., 122, 7-30, 2004.

Wulf, S., Keller, J., Paterne, M., Mingram, J., Lauterbach, S., Opitz, S., Sottili, G., Giaccio, B., Albert, P. G., Satow, C., Tomlinson, E. L., and Viccaro, M.: The 100e 133 ka record of Italian explosive volcanism and revised tephrochronology of Lago Grande di Monticchio, Quaternary Sci. Rev., 58, 104-123, 2012.

Wutke, K., Wulf, S., Tomlinson, E. L., Hardiman, M., Dulski, P., Luterbacher, J., and Brauer, A.: Geochemical properties and environmental impacts of seven Campanian tephra layers deposited between 40 and $38 \mathrm{ka} \mathrm{BP}$ in the varved lake sediments of Lago Grande di Monticchio, southern Italy. Quaternary Sci. Rev., online first, doi:10.1016/j.quascirev.2014.05.017, 2014.

Zolitschka, B. and Negendank, J. F. W.: Sedimentology, dating and palaeoclimatic interpretation of a $76.3 \mathrm{ka}$ record from Lago Grande di Monticchio, southern Italy, Quaternary Sci. Rev., 15, 101-112, 1996. 